Chirurgia (2018) 113: 412-417

No. 3, May - June

Copyright $\odot$ Celsius

http://dx.doi.org/10.21614/chirurgia.113.3.412

\title{
Laparoscopic Spleen Preserving Distal Pancreatectomy with Splenic Vessels Preservation
}

\author{
Victor Tomulescu, Catalin Copaescu \\ Ponderas Academic Hospital, Bucharest, Romania
}

Corresponding author:

Victor Tomulescu, MD

Ponderas Academic Hospital

Nicolae Caramfil 85A, Bucharest, R0

E-mail: victor.tomulescu@gmail.com

\section{Rezumat \\ Pancreatectomia distală cu conservarea splinei și prezervarea vaselor splenice}

Chirurgia modernă a pancreasului consideră pancreatectomia distală cu conservarea splinei ca procedură optimă pentru leziunile pancreatice benigne sau cu malignitate scăzută localizate la nivel corporeocaudal. Obiectivul prezentului articol este descrierea tehnicii pancreatectomiei distale cu conservarea splinei şi prezervarea vaselor splenice pe cale laparoscopică (LSPDP-SVP) precum şi rezultatele utilizării acestui procedeu în perioada 20172018 în Ponderas Academic Hospital.

Cuvinte cheie: pancreatectomia distală cu conservarea splinei, prezervarea vaselor splenice, tumori ale pancreasului, chirurgie minimal invazivă, chirurgie laparoscopică

\section{Abstract}

Spleen preserving Distal Pancreatectomy (SPDP) is commonly applied in patients with benign or low-grade malignant tumors in the body and tail of the pancreas. Our aim is to present our technique and the early results in performing laparoscopic spleen preserving distal pancreatectomy with splenic vessel preservation (LSPDP-SVP) during 2017-2018 in Ponderas Academic Hospital.

Key words: spleen preserving distal pancreatectomy, spleen vessel preservation, pancreatic tumors, minimal invasive surgery, laparoscopic surgery 


\section{Introduction}

Nowadays laparoscopic distal pancreatectomy (Lap-DP) is recognized worldwide as a feasible and highly beneficial procedure due to less invasiveness, reduction in hospital stay and complications rate (1-3). The spleen preservation is preferred due to its favorable role inregulating balance between the hematologic and immune systems $(2,4)$. Spleen preserving Distal Pancreatectomy (SPDP) is commonly applied in patients with benign or low-grade malignant tumors in the body and tail of the pancreas.

Two surgical techniques for SPDP have been described. The first technique was described by Kimura (spleen preserving distal pancreatectomy with splenic vessel preservation - SPDPSVP) and preserves the main splenic artery and vein and excises the tail of the pancreas and those small, short vascular connections to the body (5). The second technique was described by Warshaw and involves resection of the splenic vein and artery before distal pancreatectomy, and conservation of the short spleno-colic and gastric vessels to keep normal blood flow for the spleen (spleen-preserving distal pancreatectomy with splenic vessel resection - SPDP-SVR)(6,7). Spleen preserving distal pancreatectomy is considered as first choice operation for patients with benign or small low-grade malignant tumors of the body or tail of the pancreas. In such cases, where the prognosis is excellent, it seems to be more beneficial for the patient to receive a minimal invasive spleen preserving operation so as to avoid lifetime immune deficiency and thrombocytosis.

\section{Aim}

We are presenting our technique and the early results in performing Laparoscopic Spleen preserving distal pancreatectomy with splenic vessel preservation (LSPDP-SVP) in 2017-2018, in a single private institution.

\section{Technique}

The patient is placed on the surgical table in supine position ("French position"). The port

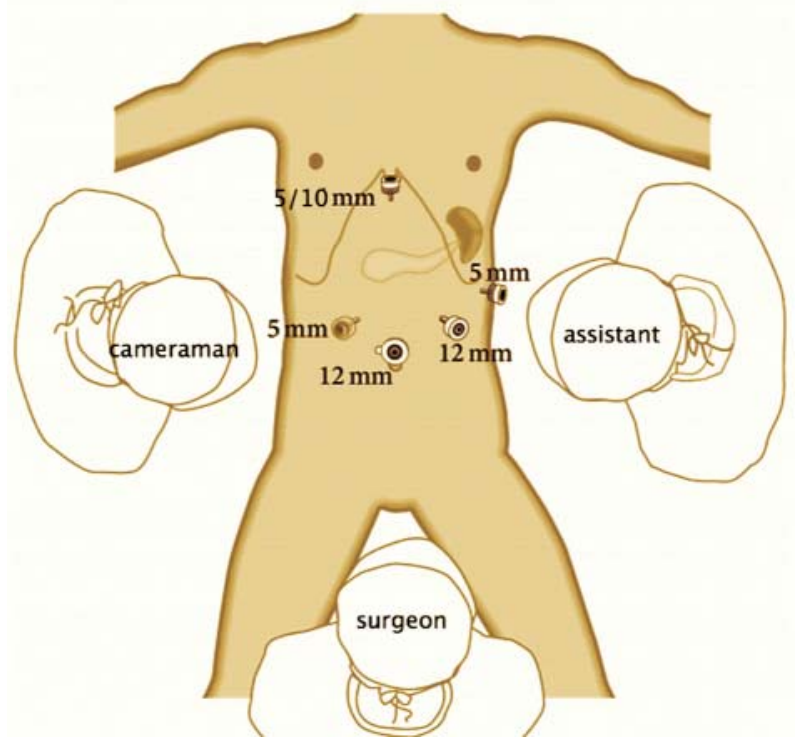

Figure 1. Patient and port position for LSPDP-SVP

position is presented in Fig 1. The trocars' scheme is: one $12-\mathrm{mm}$ trocar for the 45 degrees telescope, one $12-\mathrm{mm}$ and one $5-\mathrm{mm}$ trocar for the main surgeon, one 5-mm trocar for the first assistant, and one $5 \mathrm{~mm}$ or $12 \mathrm{~mm}$ trocar for the liver retractor.

The procedure is initiated with a careful inspection of the peritoneal surfaces, omentum, mesentery, and the viscera to rule out metastatic disease. Intraoperative ultrasound (US) can be used to evaluate the liver and localize the lesion(s) in the pancreas.

In order to perform the procedure, adequate knowledge of the pancreas surgical anatomy, consisting in blood vessels, Toldt fascia structure, the ligaments between the pancreas, the colon, the left kidney, and the diaphragm is mandatory. The fusion fascia is composed of loose connective tissue allowing the mobility of the pancreas from the retroperitoneal area, through-out a retroperitoneal or an anterior interfascial plane.

The body and tail of the pancreas are exposed by opening the lesser sac. The stomach is either fixed to the abdominal wall with a stay-suture or lifted with a Cushieri liver retractor in order to have a good visualization of the celiac trunk and splenic vessels. Sometimes only retracting the liver and adequate positioning the patients gives enough space for the procedure (Fig. 2). Mobilization of the splenic flexure of the colon start 
from lateral to medial with the spleno-colic ligament mobilization, continuing with the transverse mesocolon division at the inferior border of the pancreas using the monopolar hook. At the end, the inferior border of the pancreas and the splenic vein are exposed (Fig. 3) Posteriorly, we continue with carefully dissection of the pancreas body and then, the fascia of Toldt is cut to expose the splenic vein. The dissection starts medial to the pancreatic lesion careful being performed circumferentially around the splenic vein. Such dissection will, in addition, help identify the splenic artery at this level. Care must be taken to prevent vein inadvertent injury; sometimes small brunches that runs posteriorly have to be dissected with caution using a bipolar forceps, (classic or computer assisted) and then divided with scissors or monopolar cautery or by means of a harmonic scalpel. From our point of view KARL STORZ $\mathrm{RoBi}$ rotating bipolar forceps is the best solution due its right angle that facilitate dissection and precise and soft work on tissue. Visual magnification through the laparoscope permits excellent control of the small pancreatic veins (Fig. 4).

The upper border of the pancreas is also exposed and also the splenic artery on the superior edge of the pancreas, at the emerge from the coeliac trunk. The artery is circumferentially dissected at the pancreatic border. It can be controlled with a vessel loop which helps retracting superiorly to allow proper limphadenectomy and visualization of the splenic vein at the level of the pancreas transection.

The splenic vein is inferiorly retracted while the splenic artery is slightly superiorly lifted. Thus, we can completely encircle the body of the pancreas at the level of transection - at least $2 \mathrm{~cm}$ from the tumor, a tunnel being created between the splenic vessels and the pancreas (Fig. 5).

Once adequate mobilization of the pancreatic body has been achieved, an endos-copic stapler is placed across the body of the pancreas sparing the main splenic vessels, carefully checking anteriorly and posteriorly the stapler's positioning (Fig. 6 A, B). Alternatively, the harmonic scalpel can also be used to divide the pancreaticparenchyma.

Optimal stapling of any tissue requires an

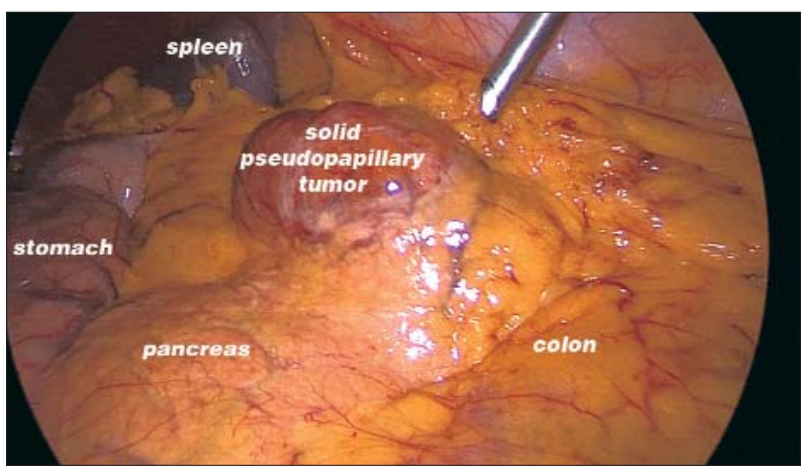

Figure 2. Initial aspect of the lesion; The body and tail of the pancreas are exposed by opening the lesser sac

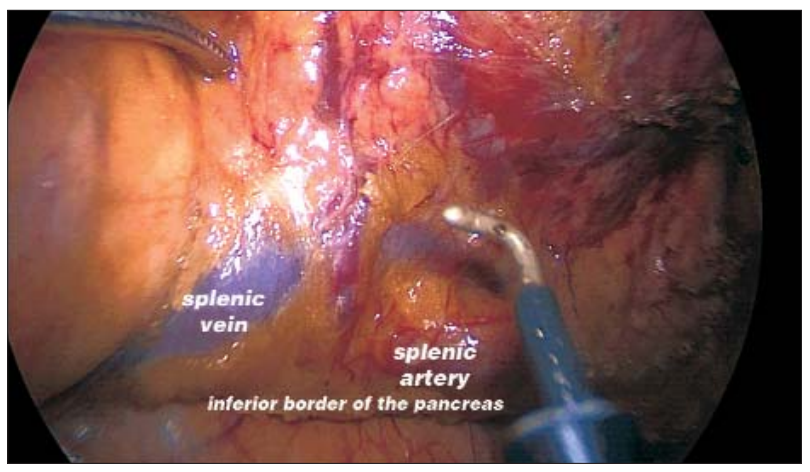

Figure 3. Posterior aspect of the pancreas

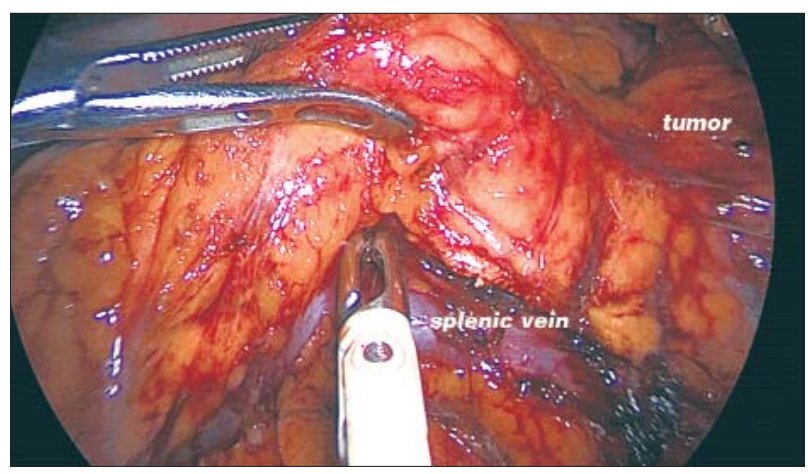

Figure 4. Dissection of the splenic vein with bipolar forceps

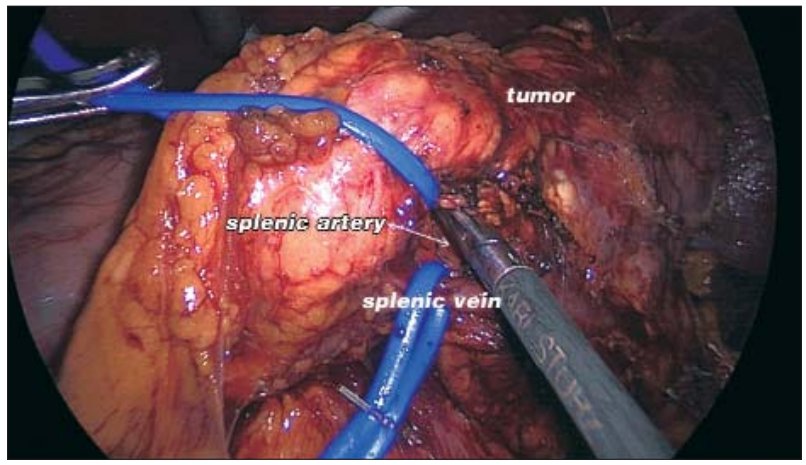

Figure 5. Evaluation of a tunnel created between the splenic vein and the pancreas 

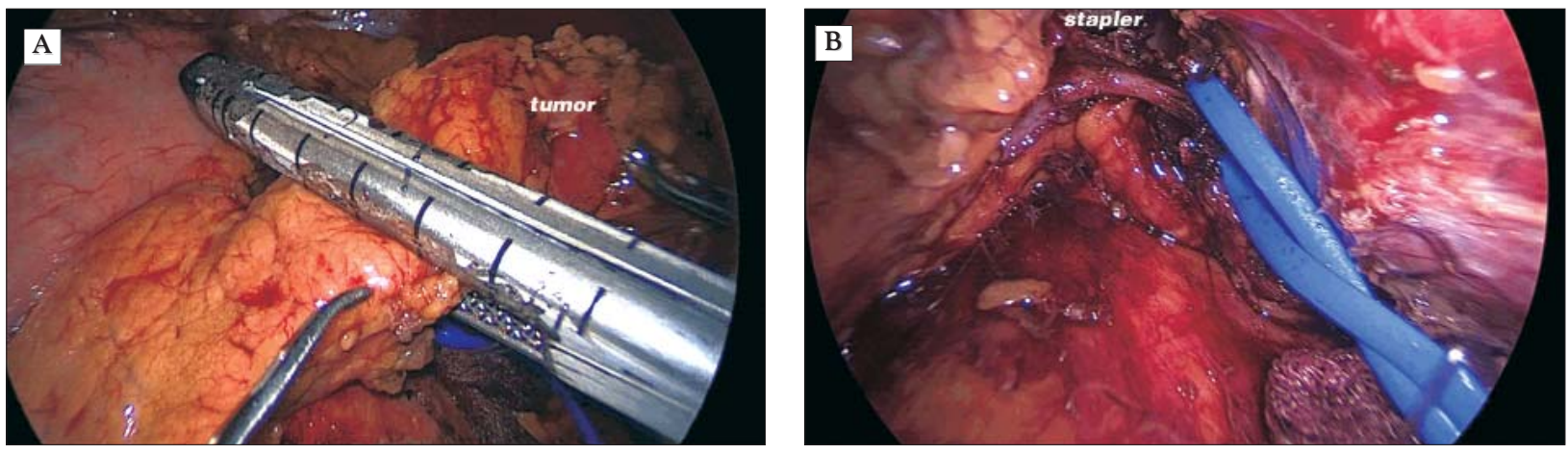

Figure 6. Stapler placement with anterior vision (a) controlling the distance from the tumor and adequate placement of the cartridge and posterior vision (b) checking splenic vessels raport

adequate tissue compression time (to decrease the fluid in the tissue) to allow elongation of the tissue being compressed, smooth firing of the instrument, consistent staple line formationbalanced against the risk of increased tissue tearing and excessive tensile strength. This is why, for pancreatic division, we prefer choosing a cartridge loaded with higher staplers asking for Tri-staple, Purple or Black [Metronic] or green or black [Ethicon). We consider that it is better to control a bleeding with clips, suture or hemostatic sponge then to experience pancreatic tissue laceration.

Once the proximal pancreatic tissue is divided, the specimen is grasped and gently retracted anteriorly to further allow dissection of the vessels in their course to the spleen. Retraction and visibility during splenic hilum dissection is facilitated by the fact the pancreas is transected. A medial-to-lateral approach is used, branches of the splenic vein are carefully dissected coagulated and sectioned with sharp scissors and, arterial bunches, which run just superior to the vein, are treated in a similar fashion taking care not to injure the adventitia of the splenic artery (Fig. 7).

After completion of the spleen-preserving distal pancreatectomy, the specimen is placed in an Endo-bag (Fig. 8) and removed via a suprapubic (Pfannenstiel) incision. When it is needed (for example in a large neuroendocrine tumor) a loco-regional lymphadenectomy is routinely performed. The pancreatic stump transection line is evaluated for bleeding and when it is needed,hemostatic clips are applied (Fig. 9).

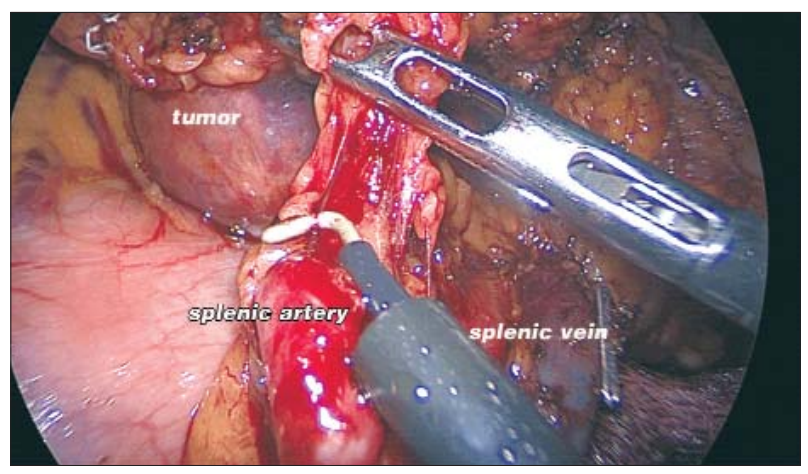

Figure 7. Splenic artery dissection

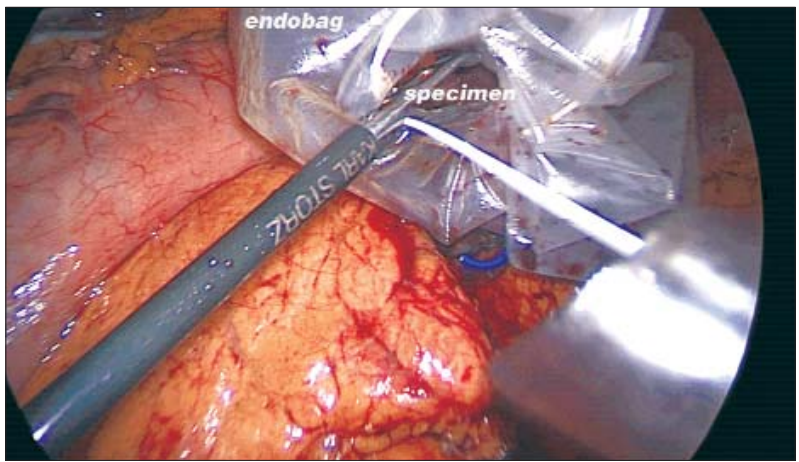

Figure 8. Placing the specimen into the endobag

In the early stages of our experience in laparoscopic distal pancreatecomy oversewing the pancreatic remnant using an absorbable suture (PDO-30) was the routine, as we learned from open surgery. Nowadays, with the new laparoscopic technology and hemostatic materials, we consider that oversewing is no longer necessary. 


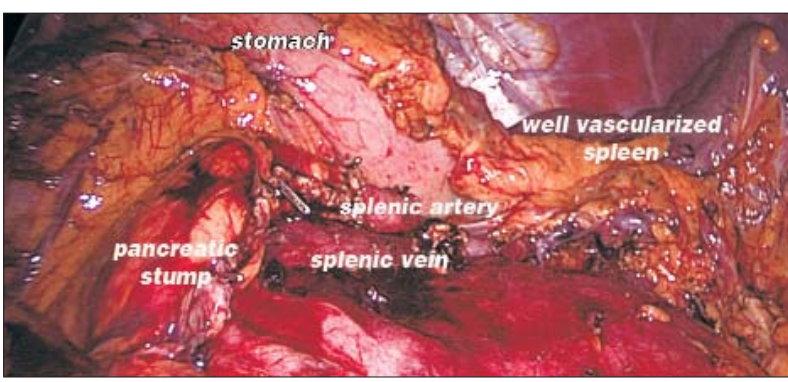

Figure 9. Final aspect after LSPDP-SVP with stapled pancreatic stump and Clips added for hemostasis, patent splenic vessels and well vascularized spleen

\section{Results}

We have used this technique in 5 cases, all of them operated during last 2 years, in a private institution (Ponderas Academic Hospital). All patients were extensively evaluated prior to surgery. Computed tomography (CT) with multi-phase intravenous contrast or contrast enhanced magnetic resonance imaging (MRI) have be performed for all patients. These studies provide information on the nature of the primary pathology and its anatomic relationship to key surrounding structures such as the splenic vessels and celiac axis. Endoscopic ultrasound (EUS) with EUS-guided fine needle aspiration (FNA) was used for characterization of cystic lesions through aspiration and cyst fluid analysis and tissue diagnosis.

Demographic characteristics, intraoperative and postoperative data are presented in Table 1.

\section{Discussions}

The topics for discussions in this technique could be related with the indications, secondly with the potential risque of splenic vein thrombosis related with extended vascular dissection and vascular trauma, and tertiary about the role of robotic surgery.

Spleen preserving laparoscopic distal pancreatectomy is considered as first choice operation for patients with benign or small low-grade malignant tumors of the body or tail of the pancreas, such as cystic tumors, IPMN, or even chronic pancreatitis (8). For pancreatic adenocarcinoma, laparoscopic en
Table 1.

\begin{tabular}{lc}
\hline Variable & \\
\hline Age $(\mathrm{y})$ & $41(32-60)$ \\
\hline Sex female & 5 cases \\
\hline Diagnosis & 2 case \\
\hline Neuroendocrine tumor & 2 case \\
\hline Solid pseudopapillary tumor & 1 case \\
\hline Accessory intrapancreatic spleen & $155(90-250)$ \\
\hline Operating time (min) & 0 \\
\hline Received blood transfusion (n,\%) & 0 \\
\hline Conversion to open (n, \%) & 0 \\
\hline Overall complications (n, \%) & $4(3-5)$ \\
\hline Postoperative hospital stay(days) & 0 \\
\hline 30-d mortality & \\
\hline
\end{tabular}

bloc resection of pancreatic tail, lymphadenectomy with splenectomy is the procedure of choice, demonstrating better oncological outcomes (5-year overall survival was $33 \%)(9,10)$. Spleen preserving distal pancreatectomy techniques at this moment are not indicated for pancreatic adenocarcinoma of the pancreatic tail, although modified Warshaw techniques have been presented with good short-term and long-term prognoses (11).

For LSPDP the difficulty is related with the splenic vessels dissection and manipulation. Primary dissection and control of main trunk of splenic artery and vein will help to quickly control bleeding during vascular rupture in small vessels dissection. Gentle actions are needed when manipulating the vessels. When the bleeding point is clear, bleeding is first controlled with a clamp. Careful suction and temporary occlusion is performed with titanium clips, and then the bleeding points are sutured with 5-0 Prolene under direct vision and then the titanium clips areremoved. If the bleeding point is not clear, gauze have to be applied for small blood vessel bleeding, and after removal of the specimen, the bleeding point can be detected and solved either by suturing or bipolar coagulation. Highly precise laparoscopic surgery requires an understanding between the main surgeon and the assistant such that in the event of bleeding, adept, timely and accurate exposure of the bleeding point can help control the bleeding within the shortest 
possible time (12). In a study that have evaluated the vascular patency after LSPDP the patients with vascular obliteration were the cases related to frequent bleeding during the operation, and many vascular manipulations were required in order toconserve splenicvessels (13). The worst scenario has to be discussed with the team and well prepared.

Robotic surgery, with three-dimensional magnified view and seven-degree articulating movement instruments, without tremor, and 3 working arms enable the operator to handle the tissue and organ with precise manipulation, and access the vessels dissection from different angles. The lack in haptic feed-back and the fact that this advanced procedure is performed only by experimented surgeons is probably the cause that the study which compared the vascular patency rate between two different minimally invasive approaches (laparoscopic vs. robotic) based on the hypothesis that robotic surgical system would be beneficial in patency of conserved splenic vessel have shown no significant statistical differences in vascular patency of conserved splenic vessels between the two groups (13).

\section{Conclusion}

LSPDP-SVP is safe, reproductible and demonstrated very good outcomes when certain indications are respected. We consider that, in centers with expertise in advanced experience in minimally invasive surgery, LSPDP-SVP should be recommended as the first choice for the treatment of benign and low-grade malignant tumors in the distal pancreas.

Conflict of Interest: none declared.

\section{References}

1. Benoist S, Dugue L, Sauvanet A, Valverde A, Mauvais F, Paye F, et al. Is there a role of preservation of the spleen in distal pancreatectomy? Journal of the American College of Surgeons. 1999; 188(3):255-60.

2. Shoup M, Brennan MF, McWhite K, Leung DH, Klimstra D, Conlon $\mathrm{KC}$. The value of splenic preservation with distal pancreatectomy. Archives of surgery. 2002;137(2):164-8.

3. Baker MS, Bentrem DJ, Ujiki MB, Stocker S, Talamonti MS. A prospective single institution comparison of peri-operative outcomes for laparoscopic and open distal pancreatectomy. Surgery. 2009;146(4):635-43; discussion 43-5.

4. Kang CM, Chung YE, Jung MJ, Hwang HK, Choi SH, Lee WJ. Splenic vein thrombosis and pancreatic fistula after minimally invasive distal pancreatectomy. The British journal of surgery. 2014; 101(2):114-9.

5. Kimura W, Moriya T, Ma J, Kamio Y, Watanabe T, Yano M, et al. Spleen-preserving distal pancreatectomy with conservation of the splenic artery and vein. World journal of gastroenterology. 2007; 13(10):1493-9.

6. Miura F, Takada T, Asano T, Kenmochi T, Ochiai T, Amano H, et al. Hemodynamic changes of splenogastric circulation after spleenpreserving pancreatectomy with excision of splenic artery and vein. Surgery. 2005;138(3):518-22.

7. Ferrone CR, Konstantinidis IT, Sahani DV, Wargo JA, Fernandez-del Castillo C, Warshaw AL. Twenty-three years of the Warshaw operation for distal pancreatectomy with preservation of the spleen. Annals of surgery. 2011;253(6):1136-9.

8. de Rooij T, Klompmaker S, Abu Hilal M, Kendrick ML, Busch OR, Besselink MG. Laparoscopic pancreatic surgery for benign and malignant disease. Nature reviews Gastroenterology \& hepatology. 2016;13(4):227-38

9. Mitchem JB, Hamilton N, Gao F, Hawkins WG, Linehan DC, Strasberg SM. Long-term results of resection of adenocarcinoma of the body and tail of the pancreas using radical antegrade modular pancreatosplenectomy procedure. Journal of the American College of Surgeons. 2012;214(1):46-52.

10. Sahakyan MA, Kazaryan AM, Rawashdeh M, Fuks D, Shmavonyan M, Haugvik SP, et al. Laparoscopic distal pancreatectomy for pancreatic ductal adenocarcinoma: results of a multicenter cohort study on 196 patients. Surgical endoscopy. $2016 ; 30(8): 3409-18$.

11. Sun Z, Zhu Y, Zhang N. The detail of the en bloc technique and prognosis of spleen-preserving laparoscopic distal pancreatectomy for pancreatic cancer. World journal of surgical oncology. 2015;13:322.

12. Yan JF, Xu XW, Jin WW, Huang CJ, Chen K, Zhang RC, et al. Laparoscopic spleen-preserving distal pancreatectomy for pancreatic neoplasms: a retrospective study. World journal of gastroenterology. 2014;20(38):13966-72.

13. Hwang HK, Chung YE, Kim KA, Kang CM, Lee WJ. Revisiting vascular patency after spleen-preserving laparoscopic distal pancreatectomy with conservation of splenic vessels. Surgical endoscopy. 2012;26(6):1765-71. 